\title{
光子の量子力学の構成および古典電磁気学との関係
}

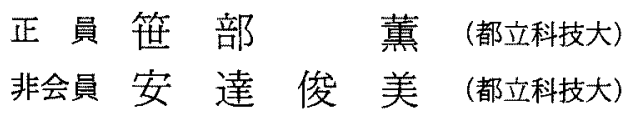

\section{Construction of Quantum Mechanics for photon and Relations with Classical Electromagnetism}

Shigeru Sasabe, Member, Toshimi Adachi, Non-member (Tokyo Metropolitan Institute of Technology)

Following the preceding work, quantum mechanics for the photon is again investigated. First, the second-quantization of the free photon fields is carried out by means of the Lagrangian formalism. Operators of the momentum, of the Hamiltonian, and of the photon number of the system are obtained. Secondly, the interaction of first-quantized photon with the potential is investigated. Correspondence of our theory to the classical electromagnetic theory is also found.

キーワード：光子, 電磁界, 光学ポテンシャル, 第二量子化

\section{1. 序論}

光を粒子的に記述する光子の概念が導入されて以 来, 1 世紀近くが経過した。その間, 光と物質との相 互作用を記述する量子電磁力学という見事な理論体系 が, 朝永やSchwinger, Feynmanによって完成され た。この理論は光子と電子の相互作用を扱う限り, 完 全に近い実験との一致と予言能力をもっている。ま た, 1963 年に Glauberによって光の状態のコヒーレ ント表示が発見されて, 量子光学の幕開けを迎えた。 しかし, その後の量子光学の発展と光技術の急速な進 歩は，上述の優れた理論体系があるにもかかわらず, 物理空間での光子の振舞いについて, 詳細な知識を必 要とするようになった。このために，多くの研究者に よって幾つかの試みが成されてきだ(1)。

著者らも, さきの論文 ${ }^{(2)}$ で, 光子の物理空間での運 動を記述するものとして Schrödinger 形の方程式を 提案し, 主として自由光子の場合について論じてき た。しかしながら, 荷電粒子との相互作用をどのよう に考えるかという問題は残されたままであった。ま た，量子光学的な見方に対応する議論も成されていな い。この論文では，これらの残された幾つかの問題に ついて考察してみたい。

電学論A, 111 巻 1 号, 平成 3 年
量子光学に対応する議論として, 前論文で導入した 自由光子に対する波動方程式を，そのまま場の方程式 とみての第二量子化を第 2 章, 第 3 章で示す。そこで は，自由光子に対するラグランジアンを設定し，場の 理論の一般論に従って量子化の手続きを行う。ここで は，自由光子の記述に関して，極めて合理的な結果を 得ている。

次に, 荷電粒子との相互作用の問題を第 4 章で述べ る。量子電磁力学では, 光子と荷電粒子の相互作用を 決定する際に, ゲージ不変性を指導原理とすることが できた。これに対し，光子の運動を記述する我々の理 論では，相互作用を決定する指導原理はわかっていな いが,これに対する一つの手掛加りは, 古典電磁気学 との幅広い対応関係にあろう。これについては第 5 章 で議論される。なお, 本論文中の数式はすべて, cgs, Gauss 単位系で記述されている。

\section{2. ラグランジアン形式 (自由光子の場合)}

次章での第二量子化のために，本章ではラグランジ アン形式による定式化を進めていく〔ラグランジアン 形式に関しての詳細は参考文献（3）または（4）を参照 されたいるこの方式によれば，最初に適切なラグラ ンジアンを設定するだけで, 後は定められた手順に従 
つて計算してゆけば自動的に第二量子化が実現する。 我々は自由光子に対して， $\Phi_{k}$ 扔よび $\widetilde{\Phi}_{k}$ を場の量と して次のようにラグランジアン密度を与える。

$$
\begin{aligned}
\mathcal{L}= & -\hbar c \varepsilon_{k l m} \Phi_{k}^{*} \partial_{l} \Phi_{m}+i \hbar \Phi_{h}^{*} \partial_{0} \Phi_{k} \\
& +\hbar c \varepsilon_{k l m} \widetilde{\Phi}_{k}^{*} \partial_{l} \widetilde{\Phi}_{m}+i \hbar \widetilde{\Phi}_{k}^{*} \partial_{0} \tilde{\Phi}_{k}
\end{aligned}
$$

ただし $\hbar=h / 2 \pi, h:$ プンンク定数, $c$ :

光速

$$
\Phi=\Phi(x),(x) \equiv(\boldsymbol{r}, t)
$$

ここで, $\partial_{k}=\partial / \partial x_{k}(k=1,2,3), \partial_{0}=\partial / \partial t て ゙ あ り$, $\varepsilon_{k l m}$ は添字について完全反対称な単位擬テンソルであ る。また，二重の添字については縮約を表しているも のと約束する $\left(A_{k} B_{k}=A_{1} B_{1}+A_{2} B_{2}+A_{3} B_{3}\right)$ 。古典場 の理論加ら導出される Euler の方程式は

$$
\frac{\partial \mathscr{L}}{\partial \varphi}-\partial_{k}\left(\frac{\partial \mathscr{L}}{\partial\left(\partial_{k} \varphi\right)}\right)-\partial_{0}\left(\frac{\partial \mathscr{L}}{\partial\left(\partial_{0} \varphi\right)}\right)=0
$$

ここで， $\varphi$ はラグランジアンに含まれる変数としての

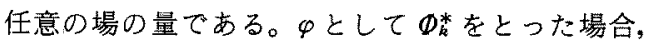
(2)式により (1)式のラグランジアン密度から得られ る場の運動方程式は,

$$
i \hbar \partial_{0} \Phi_{k}=\hbar c \varepsilon_{k l m} \partial_{l} \Phi_{m}
$$

となる。また，上式に共役な方程式は

$$
-i \hbar \partial_{0} \Phi_{k}^{*}=\hbar c \varepsilon_{k l m} \partial_{l} \Phi_{m}^{*}
$$

である。ここに，右肩の*記号は $C$-数に対しては複 素共役を, 演算子に対しては共役虚な演算子を表すも のと約束する。(3a)式は先の論文 ${ }^{(2)}$ において，自由 光子の Schrödinger 方程式として我々が得たものと 同一である。しかしながら，(3a)式に扔いては $\Phi_{k}$ はすでに光子の状態関数ではなく，(3a) 式は電磁界 を代表する場の量としての $\Phi_{k}$ が満たす運動方程式と

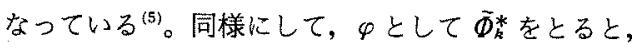

$$
i \hbar \partial_{0} \widetilde{\Phi}_{k}=-\hbar c \varepsilon_{k i m} \partial_{l} \widetilde{\Phi}_{m}
$$

を得る。これに共役な方程式は，

$$
i \hbar \partial_{0} \tilde{\Phi}_{k}^{*}=\hbar c \varepsilon_{k i m} \partial_{l} \tilde{\Phi}_{m}^{*}
$$

さて， $\theta$ を任意のスカラ量として，(1)式のラグラン ジアン密度は,

$$
\Phi_{k} \rightarrow \Phi_{k} e^{i \theta}
$$

および,これに共役な

$$
\Phi_{k}^{*} \rightarrow \Phi_{k}^{*} e^{-i \theta}
$$

なる位相変換に対して不変である。従って, Noether

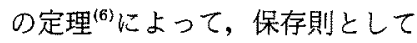

$$
\begin{aligned}
& \frac{\partial}{\partial x_{k}}\left[\frac{\partial \mathscr{L}}{\partial\left(\partial \Phi_{m}\right)} \Phi_{m}-\Phi_{m}^{*} \frac{\partial \mathscr{L}}{\partial\left(\partial_{k} \Phi_{m}^{*}\right)}\right] \\
& \quad+\frac{\partial}{\partial t}\left[\frac{\partial \mathscr{L}}{\partial \dot{\Phi}_{k}} \Phi_{k}-\Phi_{k}^{*} \frac{\partial \mathscr{L}}{\partial \dot{\Phi}_{k}^{*}}\right]=0
\end{aligned}
$$

が成り立つ。ここで, $の$ の上のドットは時刻 $t に よ$
る微分を表す。そこで，

$$
\begin{aligned}
& \rho \equiv \frac{1}{i \hbar}\left[\frac{\partial \mathcal{L}}{\partial \dot{\Phi}_{k}} \Phi_{k}-\Phi_{k}^{*} \frac{\partial \mathcal{L}}{\partial \dot{\Phi}_{k}^{*}}\right] \cdots \cdots \cdots \cdots \cdots . . . \\
& J_{k} \equiv \frac{1}{i \hbar}\left[\frac{\partial \mathcal{L}}{\partial\left(\partial_{k} \Phi_{m}\right)} \Phi_{m}-\Phi_{m}^{*} \frac{\partial \mathcal{L}}{\partial\left(\partial_{k} \Phi_{m}^{*}\right)}\right]
\end{aligned}
$$

と定義すると，(5)式の保存則は

$$
\frac{\partial \rho}{\partial t}+\operatorname{div} \boldsymbol{J}=0
$$

と表される。（6)式の定義によって(1)式のラグラン ジアンから $\rho, \boldsymbol{J}$ としてそれぞれ

$$
\begin{aligned}
& \rho=\Phi_{k}^{*} \Phi_{k} \\
& J_{k}=-i c \varepsilon_{k l m} \Phi_{l}^{*} \Phi_{m}
\end{aligned}
$$

が得られる。これは前論文にて得られた, 光子の確率 密度 $\rho=\Phi^{*} \boldsymbol{\Phi}$ と確率流の密度 $\boldsymbol{J}=(c / i) \boldsymbol{\Phi}^{*} \times \boldsymbol{\Phi}$ その ものである。ただし，(3)式に見るように，著者らは エネルギー $E>0$, ヘリシティー $\lambda=+1$ の光子の満た す場の方程式と， $E>0, \lambda=-1$ の光子のそれとは独 立な存在としているので, 本論文ではこれらの量もそ れぞれの光子に対応して 2 種類考えることができる。 実際，(4)式と同样の $\widetilde{\Phi}_{k}$ に関する位相変換に対する Lの不変性から, 保存則として再び $(7)$ 式を得る。た だし，今度の場合は

$$
\begin{aligned}
& \rho=\tilde{\Phi}_{k}^{*} \tilde{\Phi}_{k} \quad \ldots \ldots . . . \\
& J_{k}=i c \varepsilon_{k l m} \tilde{\Phi}_{l}^{*} \tilde{\Phi}_{m}
\end{aligned}
$$

である。それゆえに，今後は両者を区別すべく，それ ぞれの物理量に(+)，(）の添字を加えることにしよ う。以上をまとめると,

$$
\begin{aligned}
& \rho^{(+)}=\boldsymbol{\Phi}^{*} \boldsymbol{\Phi} \\
& \boldsymbol{J}^{(+)}=-i c \boldsymbol{\Phi}^{*} \times \boldsymbol{\Phi} \\
& \frac{\partial \rho^{(+)}}{\partial t}+\operatorname{div} \boldsymbol{J}^{(+)}=0 \\
& \rho^{(-)}=\tilde{\boldsymbol{\Phi}}^{*} \tilde{\boldsymbol{\Phi}} \ldots \ldots \ldots \\
& \boldsymbol{J}^{(-)}=i c \tilde{\boldsymbol{\Phi}}^{*} \times \tilde{\boldsymbol{\Phi}} \\
& \frac{\partial \rho^{(-)}}{\partial t}+\operatorname{div} \boldsymbol{J}^{(-)}=0
\end{aligned}
$$

さて，(3) 式が光子の波動方程式 (Schrödinger 方程 式）であった第一量子化の段階では，さきに述べたと

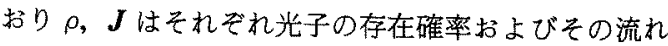
の密度を意味していたが，（3 式を場の方程式とみる 今の場合は，両者はそれぞれ光子数密度および光子の 流れの密度の演算子と解釈すべきである。

\section{3. 場の量子化}

本章では前章で与えられたラグランジアンを基にし て，所定の手続きに従って場の量子化を行う。ラグラ 
ンジアン $(1)$ 式から得られる， $\Phi_{k}$ に正準共役な運動 量は

$$
\Pi_{k}=\frac{\partial \mathscr{L}}{\partial \dot{\Phi}_{k}}=i \hbar \Phi_{k}^{*}
$$

また, $\widetilde{\Phi}_{k}$ に正準共役な運動量は

$$
\tilde{\Pi}_{k}=\frac{\partial \mathcal{L}}{\partial \tilde{\Phi}_{k}}=i \hbar \tilde{\Phi}_{k}^{*}
$$

正準形式理論から要求される同時刻交換関係は次の通 りである。

$$
\begin{aligned}
& {\left[\Phi_{k}(x), \Pi_{l}(y)\right]_{E T} }=i \hbar \delta_{k l} \delta^{3}(x-y) \quad \cdots(15 \mathrm{a}) \\
& {\left[\Phi_{k}(x), \Phi_{l}(y)\right]_{E T} }=\left[\Pi_{k}(x), \Pi_{l}(y)\right]_{E T}=0 \\
& \cdots \cdots \cdots \cdots \cdots \cdots \cdots \cdots \cdots \cdots \cdots \cdots \cdots \cdots \cdots \cdots \cdots \cdots \cdots \cdots \cdots \cdots \cdots \cdots \\
& {\left[\tilde{\Phi}_{k}(x), \tilde{\Pi}_{l}(y)\right]_{E T} }=i \hbar \delta_{k l} \delta^{3}(x-y) \quad \cdots(15 \mathrm{c}) \\
& {\left[\tilde{\Phi}_{k}(x), \tilde{\Phi}_{l}(y)\right]_{E T} }=\left[\tilde{\Pi}_{k}(x), \tilde{\Pi}_{l}(y)\right]_{E T}=0
\end{aligned}
$$

あるいは，(14)式の各式を代入すれば,

$$
\begin{aligned}
& {\left[\Phi_{k}(x), \Phi_{l}^{*}(y)\right]_{E T}=\delta_{k l} \delta^{3}(x-y)} \\
& \left\{\Phi_{k}(x), \Phi_{l}(y)\right\}_{E T}=\left[\Phi_{k}^{*}(x), \Phi_{l}^{*}(y)\right]_{E T}=0 \\
& {\left[\widetilde{\Phi}_{k}(x), \widetilde{\Phi}_{l}^{*}(y)\right]_{E T}=\delta_{k l} \delta^{3}(x-y)} \\
& {\left[\tilde{\Phi}_{k}(x), \widetilde{\Phi}_{l}(y)\right]_{E T}=\left[\tilde{\Phi}_{k}^{*}(x), \widetilde{\Phi}_{l}^{*}(y)\right]_{E T}=0}
\end{aligned}
$$

を得る。ここで, 括弧右側の添字〔ET」は同時刻 (Equal Time)であることを示す。

ハミルトニアン密度は

$$
\mathscr{H}=\Pi_{k} \dot{\Phi}_{k}+\tilde{\Pi}_{k} \dot{\Phi}_{k}-\mathcal{L}
$$

で与えられる。（14）式および(1)式を代入すれば,

$$
\mathscr{H}=\hbar c \varepsilon_{k l m} \Phi_{k}^{*} \partial_{l} \Phi_{m}-\hbar c \varepsilon_{k l m} \widetilde{\Phi}_{k}^{*} \partial_{l} \widetilde{\Phi}_{m}
$$

を得る。これにより，系のハミルトニアンとして

$$
\begin{aligned}
H= & \int d^{3} x \mathcal{H}(x) \\
= & \hbar c \varepsilon_{k l m} \int d^{3} x \Phi_{k}^{*} \partial_{l} \Phi_{m} \\
& -\hbar c \varepsilon_{k l m} \int d^{3} x \tilde{\Phi}_{k}^{*} \partial_{l} \tilde{\Phi}_{m}
\end{aligned}
$$

が与えられる。

第 2 章において，著者らは与えられたラグランジア ンから, Eulerの運動方程式に基づいて場の方程式(3 a)式を得た。一方において, 正準形式理論では運動 方程式としていわゆるハイゼンベルグの方程式

$$
\frac{d \varphi}{d t}=\frac{1}{i \hbar}[\varphi, H]
$$

ただし， $\varphi(t)$ : 陽に時刻 $t$ に依存しない

があり，正しい量子化によって両者が等価になること がよく知られている。以下において，光子の運動方程 式(3a)が実際にハイゼンベルグの方程式(20)から導 出できる事実を示そう。この事実は，我々の量子化の 手続きである(15)式および(16)式の正当性を保証する ものである。(19)式を用いて，方程式(20)から

$$
\begin{aligned}
i \hbar \partial_{0} \Phi_{j}(x)= & {\left[\Phi_{j}(x), H\right] } \\
= & \hbar c \varepsilon_{k l m} \int d^{3} y\left[\Phi_{j}(x), \Phi_{k}^{*}(y)\right]_{E T} \\
& \times \partial_{l} \Phi_{m}(y) \cdots \cdots \cdots \cdots \cdots \cdots \cdots(2
\end{aligned}
$$

これに，交換関係(16)式を用いれば上式は

$$
i \hbar \partial_{0} \Phi_{k}=\hbar c \varepsilon_{k l m} \partial_{l} \Phi_{m}
$$

となる。こうして, 著者らは再び $(3 \mathrm{a})$ 式を得た。全 く同様にして $\check{\emptyset}$ に対する方程式 $(3 \mathrm{c})$ 式も得ることが できる。

更に, ハイゼンベルグの運動方程式を使って得られ るもう一つの興味深い事実を示しておこう。

$$
\begin{aligned}
& \frac{d}{d t}(\operatorname{div} \boldsymbol{\Phi})=\frac{1}{i \hbar} \partial_{k}\left[\Phi_{k}, H\right] \\
& =-i c \varepsilon_{k l m} \partial_{k} \partial_{l} \Phi_{m} \\
& =0
\end{aligned}
$$

由元に

$$
\operatorname{div} \boldsymbol{\Phi}=\text { 定数 }
$$

ここで, 単位擬テンソル $\varepsilon_{k l m}$ の完全反対称性の性質 を使った。前論文に抢いては $\operatorname{div} \boldsymbol{\Phi}=0$ は (3a)式の補 助的な付加条件(5)であったが，本論文の形式によって (24)式が自然に導かれる。真空中においては(24)式の 右辺を 0 とすべきであるのは言うまでもない。

本章の最後として, 系を特徵づける各物理量を求め て抢こう。ラグランジアン形式では, 系の全運動量 $P$ は次式で与えられる。

$$
P_{k}=-\int d^{3} x \Pi_{l} \partial_{k} \Phi_{l}-\int d^{3} x \tilde{\Pi}_{l} \partial_{k} \tilde{\Phi}_{l}
$$

（14）式を代入すれば次式を得る。

$$
\begin{aligned}
P_{k}= & \int d^{3} x \Phi_{l}^{*}(x) \bar{p}_{k} \Phi_{l}(x) \\
& +\int d^{3} x \widetilde{\Phi}_{l}^{*}(x) \bar{p}_{k} \tilde{\Phi}_{l}(x)
\end{aligned}
$$

たたし， $\bar{p}_{k}$ は

$$
\bar{p}_{k} \equiv-i \hbar \frac{\partial}{\partial x_{k}}
$$

で定義される。また，(3)式を(19)式に代入すれば， 系のハミルトニアンも

$$
\begin{aligned}
H= & \int d^{3} x \Phi_{l}^{*}(x) \bar{E} \Phi_{l}(x) \\
& +\int d^{3} x \tilde{\Phi}_{l}^{*}(x) \bar{E} \bar{\Phi}_{l}(x)
\end{aligned}
$$

と表すことができる。ここで， 


$$
\bar{E} \equiv i \hbar \frac{\partial}{\partial t}
$$

である。更に全光子数 $N$ 㹥次式で与えられる。

$$
\begin{aligned}
& N^{(+)}(t)=\int d^{3} x \rho^{(+)}(x)=\int d^{3} x \Phi_{k}^{*}(x) \Phi_{k}(x) \\
& N^{(-)}(t)=\int d^{3} x \rho^{(-)}(x)=\int d^{3} x \tilde{\Phi}_{k}^{*}(x) \tilde{\Phi}_{k}(x)
\end{aligned}
$$

$$
N(t)=N^{(+)}+N^{(-)} .
$$

これにハイゼンベルグの方程式(20)を適用すれば,

$$
\begin{aligned}
& \frac{d N^{(+)}}{d t}=\frac{1}{i \hbar}\left[N^{(+)}, H\right] \\
& =-i c \varepsilon_{k l m} \iint d^{3} x d^{3} y \Phi_{n}^{*}(x) \\
& \times\left[\Phi_{n}(x), \Phi_{k}^{*}(y)\right]_{E T} \partial_{l} \Phi_{m}(y) \\
& -i c \varepsilon_{k l m} \iint d^{3} x d^{3} y \Phi_{k}^{*}(y) \partial_{l}^{\prime} \\
& \times\left[\Phi_{n}^{*}(x), \Phi_{m}(y)\right]_{E T} \Phi_{n}(x) \\
& =-i c \varepsilon_{k i m} \int d^{3} x \partial_{l}\left\{\Phi_{k}^{*}(x) \Phi_{m}(x)\right\} \\
& =0
\end{aligned}
$$

ここで,ダッシュの付いた偏微分記号は積分内では $\partial_{l} \equiv \partial / \partial y_{\ell}$ の意味である。また， に減少して，その表面積分が零になるものとした。同 様に, $N^{(-)}$にいても

$$
d N^{(-)} / d t=0
$$

であり, 従って

$$
d N / d t=0
$$

を得る。それゅえ，自由光子については $N=$ 定数と なり, 系の全光子数は保存される。この事実は局所的 な光子の保存䐓である(11)式抢よび(13)式からも直ち に導かれる。

\section{4. 相互作用を含む光子の量子力学}

本章では, さきの論文 ${ }^{(2)} に$ 続いて再び光子の量子力 学に立ち戻ろう。それゆえ $\Phi_{k}, \tilde{\Phi}_{k}$ 恃本章では確率関 数としての意味をもつ波動関数である(5)。先の論文で は, 相互作用のない自由光子についてのみ考察してき た。しかし, 現実の電磁気現象の多くは荷電粒子との 相互作用によって引き起こされるものである。それゆ え, 本研究も, 光子と荷電との間の相互作用を矛盾な く導入することによって，はじめて有用な理論と成り 得るであろう。本章では種々の可能性のうちから, 特 に相互作用がポテンシャルエネルギー (以後, 単にポ テンシャルと呼ぶ）の形に畫けるものについて考察し
てみたいと思う。

光子の波動方程式として

$$
i \hbar \partial_{b} \Phi_{k}(x)=\hbar c \varepsilon_{k l m} \partial_{l} \Phi_{m}(x)+\Omega_{k l}(\boldsymbol{r}) \Phi_{l}(x)
$$

を仮定する。右边第 2 項の $\Omega=\left\{\Omega_{k l}(r)\right\}$ は $3 \times 3$ 行列 て，陽に時刻 $t$ を含まないものとする。また， $\Omega$ は エネルギーの次元をもち, 座標のみの関数であるとい う意味でポテンシャルエネルギーと呼んでいるが, 通 常のポテンシャルエネルギーとは異質のものである。 荷電粒子に動く通常のポテンシャルとは, 電磁界を媒 介として荷電粒子間に生じる位置エネルギーを表して いるが， $\Omega$ の場合はむしろ，空間の各点における光 子と荷電との直接の相互作用の強さを表すものであっ て, 光子間の位置エネルギーではない。これについて は, 第 6 章で再び触れる。

自由光子の場合に， $\widetilde{\Phi}_{k}$ の満たす波動方程式が形式

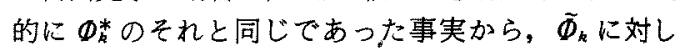
ては

$$
-i \hbar \partial_{0} \tilde{\Phi}_{k}(x)=\hbar c \varepsilon_{k l m} \partial_{l} \tilde{\Phi}_{m}(x)+\Omega_{k l}^{*}(\boldsymbol{r}) \tilde{\Phi}_{l}(x)
$$

を仮定する。（35）（36)式に共役な方程式としてそれ それ

$$
-i \hbar \partial_{0} \Phi_{k}^{*}(x)=\hbar c \varepsilon_{k l m} \partial_{l} \Phi_{m}^{*}(x)+\Omega_{k l}^{*}(\boldsymbol{r}) \Phi_{l}^{*}(x)
$$

$i \hbar \partial_{b} \tilde{\Phi}_{k}^{*}(x)=\hbar c \varepsilon_{k l m} \partial_{l} \widetilde{\Phi}_{m}^{*}(x)+\Omega_{k l}(\boldsymbol{r}) \check{\Phi}_{l}^{*}(x)$

を得る。以上の 4 式を光子の満たす基本方程式とし て、これから, 物理的に意味のある種々の関係式を導 こう。最初に, $\lambda=+1$ 光子の確率密度 $\rho^{(+)}(t)$ の時間 変化を求めると,

$$
\begin{aligned}
\frac{\partial \rho^{(+)}}{\partial t}= & \frac{\partial \Phi_{k}^{*}}{\partial t} \Phi_{k}+\Phi_{k}^{*} \frac{\partial \Phi_{k}}{\partial t} \\
= & i c \partial_{k}\left(\varepsilon_{k l m} \Phi_{l}^{*} \Phi_{m}\right)+\frac{i}{\hbar}\left\{\left(\Phi_{k}^{*} \Omega_{k l} \Phi_{l}\right)^{*}\right. \\
& \left.-\left(\Phi_{k}^{*} \Omega_{k l} \Phi_{l}\right)\right\} \quad \ldots \ldots \ldots \ldots \ldots \ldots \ldots(39)
\end{aligned}
$$

ゆえに, 確率密度の保存則

$$
\frac{\partial \rho^{(+)}}{\partial t}+\operatorname{div} \boldsymbol{J}^{(+)}=\frac{2}{\hbar} \operatorname{Im}\left\{\Phi_{k}^{*} \Omega_{k l} \boldsymbol{\Phi}_{l}\right\}
$$

を得る。ただし、ここで記号 $\operatorname{Im} は$

$$
\operatorname{Im} A \equiv \frac{A-A^{*}}{2 i} \text {. }
$$

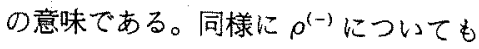

$$
\frac{\partial \rho^{(-)}}{\partial t}+\operatorname{div} J^{(-)}=-\frac{2}{\hbar} \operatorname{Im}\left\{\bar{\Phi}_{k}^{*} \Omega_{k l}^{*} \tilde{\Phi}_{l}\right\}
$$


を得る。あるいは，右辺を書き直してそれぞれ

$$
\begin{aligned}
& \frac{\partial \rho^{(+)}}{\partial t}+\operatorname{div} J^{(+)}=\frac{1}{i \hbar} \Phi_{k}^{*}\left(\Omega-\Omega^{\dagger}\right)_{k l} \Phi_{l} \\
& \text {........................... (43 a) } \\
& \frac{\partial \rho^{(-)}}{\partial t}+\operatorname{div} \boldsymbol{J}^{(-)}=\frac{1}{i \hbar} \tilde{\Phi}_{k}\left(\Omega-\Omega^{\dagger}\right)_{k l} \tilde{\Phi}_{l}^{*}
\end{aligned}
$$

となる。ここで $\Omega^{+}$は $\Omega$ のエルミット共役な行列を 表す。ポテンシャル $\Omega$ か゚エルミット行列 $\left(\Omega^{\dagger}=\Omega\right)$ て あるならば(43)式の右辺は 0 となり, 自由光子と同じ 保存則を満たす。この場合注ポテンシャルによる光子 の弾性散乱過程を意味している。しかし， $\Omega$ がエル ミット行列でない場合は(43)式の右辺は零でない有限 の値をもち，これが光子の生成または消滅の源と なる。

いま，特に $\Omega$ が対角形の行列である場合を考えて みよう。その形を

$$
\Omega_{k l}=\delta_{k l}\{U(\boldsymbol{r})-i V(\boldsymbol{r})\}
$$

ただし， $U(\boldsymbol{r}), V(\boldsymbol{r})$ は実関数

とおくと，(43)式はそれぞれ

$$
\begin{aligned}
& \frac{\partial \rho^{(+)}}{\partial t}+\operatorname{div} \boldsymbol{J}^{(+)}=-\frac{2}{\hbar} V(\boldsymbol{r}) \rho^{(+)} \cdots \cdots \\
& \frac{\partial \rho^{(-)}}{\partial t}+\operatorname{div} \boldsymbol{J}^{(-)}=-\frac{2}{\hbar} V(\boldsymbol{r}) \rho^{(-)} \cdots \cdots
\end{aligned}
$$

と書ける。 $V(\boldsymbol{r})>0$ として，上式は単位体積あたり 単位時間に $2 V / \hbar$ の割合で各々の光子の存在確率が失 われていくことを示している。一般に，荷電と光子と の散乱現象を考えるとき，上記の事実は入射光子束か ら単位時間に $2 V / \hbar$ の割合で光子が荷電に吸収されて いく過程を表している。

非相対論的量子力学は，实の理論形式加ら本質的に 安定な粒子をその対象としている。それりえに，常に 放出と吸収を繰返す光子のごとき相対論的な粒子はそ の対象外であり，最初から生成・消隇を自然な形で取 入れることのできる，場の量子論によって取报われ ていた。そしてその代償として，光子の統計性と光子 数のみが強調されて，個々の光子の振舞いが明白な形 で記述できなかった。(45)式は確率的な光子の吸収過 程を可能としつつ，しかも個々の光子の運動を波動方 程式(35)，(36)によって記述することの可能性を我々 に与えてくれるものである。実は，このようなアプロ 一チは原子核物理学の分野で既に知られていたことで ある(7)。すなわち，普通の Schrödinger 方程式を満た す中性子束が核子に入射するとき，確率的に「核」に よる吸収が起こる。このときの入射中性子の密度が満
たす方程式が(45)式と完全に同形である。この事実は 必ずしも自明ではなく（45)式によって初めて明らか になったものである。原子核の散乱理論によれば, (44)式の形のポテンシャルはその物理的意味から, 「吸取ポテンシャル」と呼ばれているる た,「光学ポテンシャル」と呼ばれることも多い(7)。 この㭔び名の由来は，本来実数であるべきポテンシャ ルの複素数化が，ちょうど物質中での光の届折と吸収 を扱うのに, 複素数の㐿折率を導入したことに対応し ている事実に基づく。アナロジーのみによってつけら れた「光学ポテンシャル」の名称が，ここにおいて実 際に, 光の棈成要素である光子の波動方程式に再び還 元されることは，宿命的なものを感じて興味深い。

次に，自由光子では定数であった $\operatorname{div} \boldsymbol{\Phi}$ の時間変 化を求めよう。次章にみるように，この結果を古典電 磁気学の立場で考察することにより，我々が仮定した ポテンシャルの物理的特性を，より感覚的な電気的特 性に書き直すことが可能となる。(35)式の両辺を $\partial_{k}$ で微分すれば,

$$
\begin{aligned}
i \hbar \partial_{k} \partial_{0} \Phi_{k}(x)= & \hbar c \varepsilon_{k l m} \partial_{k} \partial_{l} \Phi_{m}(x) \\
& +\partial_{k}\left\{\Omega_{k l}(\boldsymbol{r}) \Phi_{l}(x)\right\} \\
= & \partial_{k}\left\{\Omega_{k l}(\boldsymbol{r}) \Phi_{l}(x)\right\}
\end{aligned}
$$

ここで, 再び $\varepsilon_{k l m}$ の完全反対称性を使った。いま, $\Omega$ が(44)式と同じく対角形で，かつ座標によらず一 様なポテンシャルである場合を考党ると，(44) 式は

$$
\Omega_{k i}=\delta_{k l}\left(U_{0}-i V_{0}\right)
$$

ただし， $U_{0}, V_{0}$ : 実数

と書ける。ゆえに(46)式は

$$
\frac{d(\operatorname{div} \boldsymbol{\Phi})}{d t}=\frac{\left(U_{0}-i V_{0}\right)}{i \hbar} \operatorname{div} \boldsymbol{\Phi}
$$

と表せる。この解㹥次式で与えられる。

$$
\begin{aligned}
\operatorname{div} \boldsymbol{\Phi}(x)= & \operatorname{div} \boldsymbol{\Phi}(\boldsymbol{r}, 0) e^{-i\left(U_{0} t / n\right)} \\
& \times e^{-\left(v_{0} t / \hbar\right)} \ldots \ldots \ldots \ldots \ldots
\end{aligned}
$$

すなわち，一様なポテンシャル中では $\operatorname{div} \Phi$ 注滅衰 する振動波の様相を呈する。

\section{5. 古典電磁気学との関係}

著者らはさきの論文で，多数の光子がコヒーレント

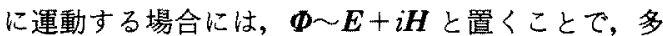
くの事例について光子の量子力学と古典電磁気学の間 に対応関係がつく事䒠をみてきた。今回もその方法を 適用して, 我々が得た結果の古典電磁気学的な理解を 試みよう。

今回は，ポテンシャルの形で荷電と光子の相互作用 が導入されており，ポテンシャルは個々の光子を確率 
的に吸収（または放出）する役目を担っている。それ はあくまても光子と荷電との微視的かつ直接的な作用 であり，誘電率や導電率，あるいは透磁率などの巨視 的な電気特性で表現できるものてはない。しかし同時 に, 上記の意味の古典電磁気学的理解の可能性を否定 できないことも，また事実である。その場合は，確率 関数である $\boldsymbol{D}$ を物質波である $\boldsymbol{E}, \boldsymbol{H}$ と同等にみなす のと同じ意味で, ポテンシャルを物質の電気的特性を 表す量と同等にみなす必要がある。それゆえ，雨者の 関係が式の上で見事に得られても，それらが物理的に 等価であると考えるのは䛊りである。

真空中では $\boldsymbol{\phi} \sim \boldsymbol{E}+\boldsymbol{i} \boldsymbol{H}$ と置いたが, 後に見るよう に，物質内では

$$
\boldsymbol{\phi} \sim \sqrt{\varepsilon} \boldsymbol{E}+i \sqrt{\mu} \boldsymbol{H}
$$

ただし， $\varepsilon:$ 誘電率， $\mu:$ 透磁率

と置き換えたほうが適切である。一様な媒質では $\operatorname{div}(\sqrt{\mu} \boldsymbol{H})=0$ により, $\operatorname{div} \boldsymbol{\Phi}$ は央数である。それ ゆえ， $U_{0}=0$ のとき，すなわちポテンシャル $\Omega$ が

$$
\Omega_{k l}=-i V_{0} \delta_{k l}
$$

の純虚数の場合のみ, 古典電磁気学との対応がつく。 このとき，(49)式は

$$
\operatorname{div} \boldsymbol{E}(x)=\operatorname{div} \boldsymbol{E}(\boldsymbol{r}, 0) e^{-v_{0} t / \hbar}
$$

と書ける。これに $\operatorname{div} \boldsymbol{E}=4 \pi \rho_{e} / \varepsilon$ を代入すれば

$$
\rho_{e}(x)=\rho_{e}(\boldsymbol{r}, 0) e^{-v_{0}}
$$

となる。(53)式は金属内における電荷密度の減少の式 に一致する ${ }^{(9)} 。$ その表式は

$$
\begin{aligned}
& \rho_{e}(x)=\rho_{e}(r, 0) e^{-t / \tau} \ldots . . . . . . \\
& \text { ただし, } \tau \equiv \varepsilon / 4 \pi \sigma: \text { 緩和時間 }
\end{aligned}
$$

と書き表される。ここで，のは媒質の導電率である。 (53、式と (54) 式の比較により,

$$
\frac{V_{0}}{\hbar}=\frac{4 \pi \sigma}{\varepsilon}\left(\equiv \frac{1}{\tau}\right)
$$

を得る。ただし，前述したと扔り上の等号は「等価」 の意味ではなく，「対応がつく」の意味である。

さて，ポテンシャル形相互作用を含む光子の量子力 学と古典電磁気学との対応関係を明確にするために, マクスウェルの方程式を光子の波動方程式(35)の形に 書き直してみよう。

基本となる方程式として, 電気と磁気の間に完全な 対称性をもたせた, 拡張されたマクスウェルの方程式

$$
\begin{aligned}
& \operatorname{rot} \boldsymbol{H}=\frac{1}{c} \frac{\partial \boldsymbol{D}}{\partial t}+\frac{4 \pi}{c} \boldsymbol{J}_{e} \ldots \\
& \operatorname{rot} \boldsymbol{E}=-\frac{1}{c} \frac{\partial \boldsymbol{B}}{\partial t}-\frac{4 \pi}{c} \boldsymbol{J}_{m} \\
& \operatorname{div} \boldsymbol{D}=4 \pi \rho_{e} \quad \ldots \ldots \ldots \ldots \ldots \\
& \operatorname{div} \boldsymbol{B}=4 \pi \rho_{m}
\end{aligned}
$$

を仮定する。上式において， $\rho_{m}$ は磁荷密度であり， その流れの密度が磁荷流 $J_{m}$ である。もし， $\rho_{m} \neq 0$ で あれば，これはDiracの単極磁荷（モノポール（11)の 存在を意味する。更に媒質は一様であって

$$
\begin{aligned}
& \boldsymbol{D}=\boldsymbol{\varepsilon} \boldsymbol{E} \\
& \boldsymbol{B}=\mu \boldsymbol{H}
\end{aligned}
$$

が成り立つものとする。いま, 便宜的に

$$
\sqrt{\varepsilon} \boldsymbol{E}+i \sqrt{\mu} \boldsymbol{H} \equiv \boldsymbol{\Xi}
$$

と扔くと，(56a)，(56b)から直ちに

$$
\begin{aligned}
\operatorname{rot} \Xi= & \frac{i \sqrt{\varepsilon \mu}}{c} \frac{\partial \Xi}{\partial t}+\frac{i 4 \pi}{c} \\
& \times\left(\sqrt{\mu} J_{e}+i \sqrt{\varepsilon} J_{m}\right)
\end{aligned}
$$

を得る。ここで，

$$
\boldsymbol{J}_{e}=\sigma \boldsymbol{E}
$$

と同時に， $J_{m}$ と $\boldsymbol{B}$ との間にも同様に次の比例関係を 仮定しよう。

$$
\boldsymbol{J}_{m}=\frac{\sigma}{\varepsilon} \boldsymbol{B}
$$

すると，(59)式の右辺第 2 項の括弧内は

$$
\sqrt{\mu} J_{e}+i \sqrt{\varepsilon} J_{m}=\frac{\sigma \mu}{\sqrt{\varepsilon \mu}} \Xi \cdot
$$

と書くことができて，(59)式は結局

$$
i \hbar \frac{\partial \Xi}{\partial t}=\hbar \frac{c}{\sqrt{\varepsilon \mu}} \nabla \times \Xi-i \hbar \frac{4 \pi \sigma}{\varepsilon} \Xi
$$

となる。これは，まに光子の波動方程式 (35) と同形 の方程式である。すなわち，雨者は

$$
\begin{aligned}
& \boldsymbol{\Phi} \rightarrow \sqrt{\varepsilon} \boldsymbol{E}+i \sqrt{\mu} \boldsymbol{H} \equiv \boldsymbol{\Xi} \\
& c \rightarrow \frac{c}{\sqrt{\varepsilon \mu}} \\
& \frac{V}{\hbar} \rightarrow \frac{4 \pi \sigma}{\varepsilon}
\end{aligned}
$$

の置き換えによって，互いに結び付いていることに気 がつく。ここで注目す心゙きことは，著者らは $(56 \mathrm{~b})$ ， $(56 \mathrm{~d}) お よ ひ ゙(61)$ 式に見られる電気と磁気の対称性を 仮定したことである。微視世界の法則と巨視世界の法 則を結び付ける対応関係(64)式が物理的に確かな根扴 をもつものであれば，単極磁荷の存在を示唆する電 気・磁気対称性の仮定なしには(63)式が得られないと いう事実は, 光子の量子力学を語るうえで意味深長な ものがある。しかし，現実の古典電磁気学では $\boldsymbol{J}_{m}=$ $\rho_{m}=0$ とされており，対応関係によって古典法則を得 る際にも，もちろんこの条件は考慮す心゙きである。 (52)式はその一例である。

次に, 公式 $\operatorname{div}(\boldsymbol{E} \times \boldsymbol{H})=\boldsymbol{H} \operatorname{rot} \boldsymbol{E}-\boldsymbol{E} \operatorname{rot} \boldsymbol{H}$, 抢上 びマクスウェルの式 $(56)$ から得られる古典電磁気学の 保存則 


$$
\begin{aligned}
& \frac{\partial}{\partial t}\left(\varepsilon \boldsymbol{E}^{2}+\mu \boldsymbol{H}^{2}\right)+2 c \operatorname{div}(\boldsymbol{E} \times \boldsymbol{H}) \\
& \quad=-\frac{8 \pi \sigma}{\varepsilon}\left(\varepsilon \boldsymbol{E}^{2}+\mu \boldsymbol{H}^{2}\right)
\end{aligned}
$$

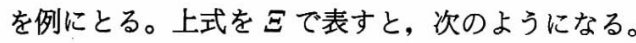

$$
\begin{aligned}
& \frac{\partial}{\partial t}\left(\Xi^{*} \cdot \Xi\right)-\frac{i c}{\sqrt{\varepsilon \mu}} \operatorname{div}\left(\Xi^{*} \times \Xi\right) \\
& \quad=-\frac{8 \pi \sigma}{\varepsilon} \Xi^{*} \cdot \Xi \ldots \ldots \ldots \ldots \ldots \ldots
\end{aligned}
$$

(66)式もやはり（64)式の置き換えによって，光子の保 存則(45 a)式から直ちに得られる。

\section{6. 最 後に}

ラグランジアン形式に基づいて自由光子場の第二量 子化が行われた。得られた結果はいずれも, 物理的に 極めて妥当かつ満足のゆくものばかりである。この事 実は著者らのアプローチの正しさを間接的に保証する ものである。光子に対する場の量子論的扱いは, 個々 の光子の運動よりも, 必然的にその個数と統計性に重点 が置かれる事実は，既に何度も述べてぎたとおりであ

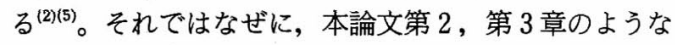
第二量子化の議論が必要であろうか？ 筆者らの理 論は, 光子に対する波動方程式〔( $3 a$ a および $(3 \mathrm{c})$ 式 と同形うをその基礎にしてきた。これまでに見たよう に, 両方から得られる結論はことごとく納得のゆくも のであるが, 両式のもつ物理的本質は未だにとらえ難 い感がある。その本質を明確にする最も良い方法は， ベクトル（およびスカラ）ポテンシャル $(\boldsymbol{A}, \phi)$ を使用 する既成の理論との相違点を明らかにすることであろ う。これが，先ほどの疑問に対する答えである。相違点 を明らかにすることによって, 相互作用まで含めて, 正しい光子の量子力学に到達することが期待される。 その相互作用の一例として, 著者らは第 4 章でポテ ンシャル内光子という形式での理論構成を試みた。そ の理由は, 粒子の量子力学からの直接のアナロジーと して,この形式が最も簡単だからである。そこでは, 光子の生成・消滅を取入れながらも, 波動方程式の形 で個々の光子の運動を議論する可能性が示された。し かし, 光子に作用するポテンシャルが与えられるとい うことは, 光子と荷電粒子との普遍的な相互作用の形 が決まったというょりも, 荷電粒子の密度と分布が定 まった結果として, 統計的（あるいは平均的）な相互 作用の「強さ」が空間の各点で決定されたのだと考え られる。従って, 荷電（あるいは電流）を半古典的 に, そして光子を量子論的に扱う事象については, こ の方向のアプローチが有用であり, その成果が期待さ
れる。しかしながら, 荷電粒子自身の量子性も無視で きない事象については, これ以外のもっと本質的な方 法が重要になると思われる。

また，著者らは第 5 章で光子の波動方程式と古典電 磁気学を結ぶ対応関係を見いだした。自由光子の場 合, その意味するところは明白であったが, ポテンシ ヤル相互作用を含を光子の場合, この対応関係の物理 的根拠は，現在のところ明らかではない。特に，電 気・磁気対称性なしにはこの関係が得られない事実は, 古典電磁気学的側面からの理解を困難にする。その解 明は，今後の興味ある課題の一つとなるであろう。

(平成 2 年 2 月 15 日受付)

\section{文献}

(1) R. J. Cook: Phys. Rev., A25, 2164 ; A26, 2754 (1982)

(2) 笹部・安達：「光子に対する量子力学の構成および Maxwell 方程式との関係」, 電学論 A, 109, 49 (平元-2)

(3) K. Nishijima :Fields and Particles (1969) W. A. Benjamin, Inc.

(4) J.D. Bjorken, S. D. Drell : Relativistic Quantum Fields (1965) McGraw-Hill

（5）細野:「「光子に対する量子力学の構成およびMaxwell 方程 式との関倸」に対する討論」, 電学論 A, 109, 558 (平元12) 笹部・安達：「同上に対する回答」，同上 $\mathrm{A} ， 109 ， 559$ (平 元-12)

(6) E. Noether : Gött. Nachr, p. 235 (1918) K. Nishijima：参考文献 ( 3 ), p.14

（7）八木：原子核物理学, 第 15 版, p. 234 (平元) 朝倉畫店 ランダウ・スモロディンスキー：原子核理論，p.113（昭 35） 丸善

（8）モット・マッセイ：衝突の理論，p.15：208（昭37）丸善

（9）高橋: 電磁気学, 第 28 版, p.126（昭 62）裳華房

(10) J.D. Jackson: Classical Electrodynamics, 2nd ed., p. 251 (1975) John Wiley \& Sons

（11）林：「モ)・ポール」(物理学最前線 6), (昭 59) 共立出版 P. A. M. Dirac: Proc. Roy. Soc., A133, 60 (1931) Phys. Rev. 74, 817 (1948)

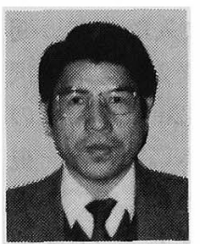

\section{笹 部薫 (正員)}

昭和 21 年 11 月 17 日生。 51 年 3 月京都大学大学院理学研究科博士課 程修了。日本学術振興会奨励研究 員, 東京都立工科短期大学講師, 同 助教授を経て, 61 年 4 月東京都立科学技術大学助教 授。理学博士。量子電磁力学および電子の物理特性の 研究に従事。日本物理学会会員。

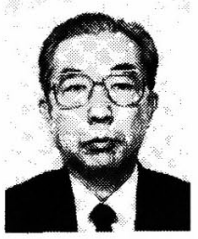

\section{安 達 俊 美 (非会員)}

昭和 5 年 1 月 21 日生。 37 年東京 都立大学大学院理学研究科修了。 43 年東京都立工科短期大学教授を経 て, 現在東京都立科学技術大学教 授。理学博士。素粒子論専攻。日本物理学会会員。 